\title{
References:
}

1. Bekh, I. D., \& Chornaya, K. I. (2008). Nacionaljna ideja $v$ stanovlenni ghromadjanyna-patriota Ukrajiny: (proghramno-vykhovnyj kontekst) [National idea in becoming a citizen-patriot of Ukraine: (program-educational context)]. Kyiv: IPV APN Ukrainy. (in Ukrainian)

2. Compass: Manual for Human Rights Education with Young people (2010). Retrieved from: https://www.coe.int/en/web/compass (accessed 15 June 2020).

3. One-page profile templates. Retrieved from: http://helensandersonassociates.co.uk/ person-centred-practice/one-page-profiles/one-page-profile-templates/ (accessed 08 September 2020).

\section{FORMATION OF INFORMATION AND DIGITAL CULTURE OF FUTURE SPECIALISTS OF PHYSICAL CULTURE AND SPORTS BY MEANS OF INFORMATION AND EDUCATIONAL ENVIRONMENT OF HIGHER EDUCATION INSTITUTION}

\section{Serhiy Lazorenko ${ }^{1}$}

\section{DOI: https://doi.org/10.30525/978-9934-26-002-5-7}

The latest trends in society require the development of the education system, in particular the training of future specialists in physical culture and sports (FK\&S), on the basis of information technology, the creation and operation of appropriate high-tech and high-quality information and educational environment. Its importance has been growing recently and qualitatively influences the process of formation and development of information and communication culture of future specialists of FC\&S. The global educational space includes a single space of the education system, which includes the information and educational environment of the free educational system, which is a set of informational, technical, educational and methodological support with established links and connects the subjects of the educational process.

The information and educational environment (I\&EE) should be perceived as the integration of the electronic campus of the educational institution, educational process management tools, pedagogical technologies designed to form an intellectually developed creative personality of FK\&S specialist, who has the necessary level of information and communication culture,

\footnotetext{
${ }^{1}$ Makarenko Sumy State Pedagogical University, Ukraine
} 
professional knowledge, skills and abilities and future professional activity in the information society.

In the information society, the communicative environment is developing rapidly, new means and channels of mass communication are being formed, and the nature of communication is changing. The close connection between information and communication through the organization of network interaction has formed the need to study such a concept as «information and communication culture». That is why the professional training of future specialists of FC\&S today should provide for the formation and development of their information and communication culture and be carried out on the basis of I\&EE.

The purpose of the article. To consider the features of the information and educational environment of the Free Economic Zone in terms of its capabilities for the formation and development of information and communication culture of future specialists FK\&S.

I\&EE includes a library of electronic educational resources (electronic textbooks, manuals, guidelines, dictionaries, reference books, laboratory workshops), which: are distributed by industry; built on the basis of Webtechnologies; can be used for various organizational forms of training; provides for the presence of a reference and search system; has a repository of external electronic resources and a repository. This involves the organization of training as an active process of acquiring knowledge that allows to develop and form a higher level of understanding and awareness of phenomena, processes, objects studied in the context of combining information resources and joint activities to achieve the goal.

The concept of I\&EE is rather ambiguously described in the scientific literature, as each author takes into account its individual features, and a single approach to the definition is not found. V. Bykov [1] noted that «the learning environment is an artificially constructed system, the structure and components of which contribute to the achievement of the goals of the educational process». Yu. Zhuk [4] defines the subject (learning) environment as an environment in which the conditions of information interaction in the learning process of a particular subject (subjects) between teacher, student and teaching aids that operate on the basis of IT. V. Lapinsky [5] states that «the learning environment is a set of material objects and connections between them, which form a system designed to ensure the educational activities of subjects of study». M. Zhaldak [3] interprets the learning environment as an artificial, man-made, system with clearly defined educational goals, which operates in a certain space, believes that the educational environment information and educational space - is a specialized and purposeful subspace of the global educational space, subsystem of a single information space of 
educational systems, the means and technologies of the latter are formed by educational institutions and subordinated to the goals of education and upbringing of a certain contingent of students taking into account the existing limitations of the educational institution on resource provision of the educational process.

Information technologies in the field of FK\&S and professional training of future $F K \& S$ specialists are used as a means of teaching and organizing intellectual leisure, for biomechanical analysis of athletes' movement techniques, creating models of training and competitive situations and as a means of automating competitions and research, and management of educational process, sports establishments and the organizations, at the organization of monitoring of a physical condition and health of those who are engaged, as means of automation of control processes, computer testing of physical, functional, mental and psychological states of those who are engaged, and correction of the results of educational and training activities.

A large number of publications cover various aspects of the use of modern IT in the pedagogical process of physical education. Scientist A. Sushchenko believes that the process of modernization of professional training of specialists in physical education and sports corresponds to the general strategy of educational policy of Ukraine today [7]. Thus, L. Denisova [2] developed and tested the effectiveness of the use in the educational process of training future specialists in physical education and sports hypermedia information environment in the discipline «Computer technology in health physical culture» in the form of a holistic electronic resource containing multimedia lecture material, interactive educational tasks, means of control of students' knowledge, information and reference system, glossary with the possibility of further placement of information material on the Internet. Thus, the ability to use a computer during training and in the professional activities of specialists in physical culture and sports becomes a necessary quality of a teacher.

This is facilitated by virtual learning environments and distance learning environments as elements of I\&EE. Virtual learning space (virtual learning space) involves the coordination of information resources with the processes of communication and activity, creating integrity, integration into a single system through which to support and direct meaningful independent learning. Platforms that support Virtual learning space include e-School.info, GIOS, OneNote and others. The distance learning space is a schematic model of the pedagogical process with the construction of training courses based on network technologies, based on an informational approach to the learning process, in terms of its structure, organization, methods of control and management. The creation of a distance course is due to the need to find new intensive ways and means of education, which moves to a new content, and 
this, of course, requires the use of modern learning tools. The relevance of the distance course is the use of web services in the educational process, which allows to diversify training sessions, to teach in practice the possession of cloud technologies, to expand the possibilities of teaching.

The organization of I\&EE as a basis for the formation of information and communication culture of future specialists FK\&S on the basis of constructivism and connectivism must meet such requirements [6, p. 78]: application of different methodological approaches to the formation and development of information and communication culture; the ability to create a network of connections between different sources of learning; activity approach to learning; formation of the ability to build information networks of physical culture and health knowledge; involvement of information technologies that help, assist in learning; organization of joint activities in the environment.

Thus, in the process of developing the information and communication culture of future specialists of FC\&S in the process of their professional training should actively use I\&EE, which, among other things, involves the development and use of educational resources (training courses with appropriate educational and methodological support). object of the educational process, to see the benefits of using IT in professional activities and to identify their own ways of self-development in a professional direction.

\section{References:}

1. Bykov, V. Yu. (2008). Modeli organizacijnyx system vidkrytoyi osvity: [monografiya] [Models of organizational systems of open education]. Kyiv: Ataka, 684 s. (in Ukrainian)

2. Goncharova, N., Denysova, L., \& Usychenko, V. (2012). Vykorystannya suchasnyx informacijnyx texnologij u sferi ozdorovchogo fitnesu [Use of modern information technologies in the field of health fitness]. Fizychne vyxovannya, sport, kultura zdorov'ya v suchasnomu suspilstvi, vol. 2, s. 163-166. (in Ukrainian)

3. Zhaldak, M. I. (2012). Pedagogichnyj potencial informatyzaciyi navchalnogo procesu. Ocinyuvannya yakosti programnyx zasobiv navchalnogo pryznachennya dlya zagalnoosvitnix navchalnyx zakladiv [Pedagogical potential of informatization of educational process. Evaluation of the quality of educational software for secondary schools]: monografiya. Kyiv. (in Ukrainian)

4. Zhuk, Yu. O. (2017). Teoretyko-metodychni zasady organizaciyi navchalnoyi diyalnosti starshoklasnykiv $\mathrm{v}$ umovax komp'yuterno oriyentovanogo seredovyshha navchannya [Theoretical and methodical bases of the organization of educational activity of senior pupils in the conditions of the computer-oriented learning environment]: monografiya. Kyiv: Pedagogichna dumka, 468 s. (in Ukrainian)

5. Lapinskyj, V. V. Elektronni osvitni resursy - dydaktychni vymogy i klasyfikaciya [Electronic educational resources - didactic requirements and classification]. URL: http://lib.iitta.gov.ua/2004 (in Ukrainian) 
6. Lytvynova, S. G. (2016). Teoretyko-metodychni osnovy proyektuvannya xmaro oriyentovanogo navchalnogo seredovyshha zagalnoosvitnogo navchalnogo zakladu [Theoretical and methodological bases of designing a cloud-oriented educational environment of a secondary school]: dys. ... dokt. ped. nauk: 13.00.10 / IITZN. Kyiv, 602 s. (in Ukrainian)

7. Sushhenko, A. V., Svatyev, A. V., Papucha, V. M., \& Mazin, V. M. (2014). Perspektyvni koncepty onovlennya profesijnoyi pidgotovky faxivciv z fizychnogo vyxovannya ta sportu [Perspective concepts of updating the professional training of specialists in physical education and sports] / Pid zagaln. red. A. V. Sushhenka. Zaporizhzhya: Vydavnycztvo ZNU, 333 s. (in Ukrainian)

\title{
ONLINE EDUCATION PROSPECTS: \\ FROM THE EXPERIENCE OF TEACHING AT THE MEDICAL UNIVERSITYDURING THE QUARANTINE PERIOD
}

\author{
Marianna Lytvynenko ${ }^{1}$ \\ Alexander Artemov ${ }^{2}$
}

DOI: https://doi.org/10.30525/978-9934-26-002-5-8

The ongoing quarantine due to the coronavirus pandemic has led to the organization of new forms of communication between teaching staff of universities and students. Online learning, which has become widespread during this period, is sometimes equated with distance learning. At the same time, one must see the difference between online teaching methods and distance learning as a special, legally stipulated form of acquiring education.

In this regard, it should be noted that the law on higher education, by default, implying the face-to-face nature of interaction during the educational process, gives an educational institution the right to establish other forms and types of the educational process. At the same time, correspondence, or distance learning, is singled out as a special form of education, which, in particular, is stated in Article 49 of the Law on Higher Education of Ukraine. The choice of full-time or part-time (distance) education is the right of the recipient of education, and not of the university, which only provides an opportunity to make such a choice.

Distance technologies as the most effective way to implement distance (correspondence) education have been talked about since the end of the last

\footnotetext{
${ }^{1}$ Odessa National Medical University, Ukraine

${ }^{2}$ State Institution «The Filatov Institute of Eye Diseases and Tissue Therapy NAMSU», Ukraine
} 